\title{
Modeling sources of nutrients in rivers draining into the Bay of Bengal-a scenario analysis
}

\author{
Simona Pedde ${ }^{1} \cdot$ Carolien Kroeze $^{2} \cdot$ Emilio Mayorga $^{3} \cdot$ Sybil Putnam Seitzinger ${ }^{4}$
}

Received: 17 October 2015 / Accepted: 19 May 2017 /Published online: 11 July 2017

(C) The Author(s) 2017. This article is an open access publication

\begin{abstract}
We model future trends in river export of nutrients to the Bay of Bengal, and the sources of this pollution. We focus on total nitrogen (TN), total phosphorus (TP), and dissolved silica (DSi) inputs to the Bay of Bengal Large Marine Ecosystem (BOB LME) in the years 2000, 2030, and 2050. In 2000, rivers exported 7.1 $\mathrm{Tg} \mathrm{N}$ and $1.5 \mathrm{Tg}$ P to the BOB LME. Three rivers (Ganges, Godavari, Irrawaddy) account for 75 $80 \%$ of the total river export of $\mathrm{N}$ and P. For 2050, we calculate an increase in river export of $\mathrm{N}$ to $8.6 \mathrm{Tg}$, while $\mathrm{P}$ export stabilizes at the 2000 level. Future trends are the net effect of increasing river export of dissolved $\mathrm{N}$ (by $40 \%$ ) and $\mathrm{P}$ (by
\end{abstract}

Editor: James Pittock

Electronic supplementary material The online version of this article (doi:10.1007/s10113-017-1176-7) contains supplementary material, which is available to authorized users.

Simona Pedde

simona.pedde@wur.nl

Carolien Kroeze

carolien.kroeze@wur.nl

Emilio Mayorga

mayorga@apl.washington.edu

Sybil Putnam Seitzinger

PICSDir@UVic.ca

1 Soil Geography and Landscape Group, Wageningen University, Droevendaalsesteeg 3, 6708 PB Wageningen, The Netherlands

2 Water Systems and Global Change Group, Wageningen University, Droevendaalsesteeg 4, 6708 PB Wageningen, The Netherlands

3 Applied Physics Laboratory, University of Washington, 1013 NE 40th St, Seattle, WA 98105-6698, USA

4 Pacific Institute for Climate Solutions, PICS, PO Box 1700, STN CSC, Victoria, BC V8W 2Y2, Canada
$80 \%$ ), and decreasing river export of particulate $\mathrm{N}$ and $\mathrm{P}$. The increases in dissolved $\mathrm{N}$ and $\mathrm{P}$ loads are associated primarily with increased $\mathrm{N}$ and $\mathrm{P}$ losses from agriculture and sewage systems. The decreasing export of particulate $\mathrm{N}$ and $\mathrm{P}$ is associated with damming of rivers and increased human water consumption. There are large differences in nutrient export among rivers. Rivers draining into the western $\mathrm{BOB}$ LME generally export more $\mathrm{N}$ and $\mathrm{P}$ than eastern BOB LME rivers. Most $\mathrm{N}$ and $\mathrm{P}$ in western $\mathrm{BOB}$ LME rivers are from anthropogenic sources. Future increases in dissolved inorganic N and P (DIN and DIP) export can be large for individual rivers: up to more than a factor of five for DIP and more than a doubling for DIN. The calculated nutrient export ratios (N and $\mathrm{P}$ relative to $\mathrm{DSi}$ ) indicate an increasing risk for blooms of non-siliceous algal species, which can potentially produce toxins and otherwise disrupt coastal ecosystems. Our results indicate that basin-specific management may be the most effective approach towards reducing the risk of coastal eutrophication in the BOB LME.

Keywords Bay of Bengal $\cdot$ River pollution $\cdot$ Coastal eutrophication $\cdot$ Nitrogen $\cdot$ Phosphorus $\cdot$ Silica

\section{Introduction}

Nutrient loads exported by rivers to coastal waters have increased in the Bay of Bengal Large Marine Ecosystem (BOB LME) in the past decades (Sattar et al. 2014), leading to changes in nutrient stoichiometry (Islam et al. 2004; Tripathy et al. 2005) and, as a consequence, harmful nonsiliceous algae blooms (Garnier et al. 2010). Hypoxia and algal blooms have been observed along the coastlines of the BOB LME (Buapet et al. 2008; Das et al. 2004; Lee and Bong 2006; Meybeck and Helmer 1989; Periyanayagi et al. 2007). 
Hypoxia may be harmful to aquatic ecosystems and result in dead zones. This, in turn, can lead to a number of negative changes in coastal ecosystems including algal blooms, alterations in community composition, production of toxic algae, hypoxic or anoxic conditions, and increased turbidity (Glibert et al. 2010; Glibert et al. 2014). Harmful algal blooms may cause socio-economic problems too, such as threats to fisheries and tourism (Bricker et al. 2008).

The rivers draining into the BOB LME cover a large area. Some of these rivers are transboundary rivers, with drainage areas in several countries. Examples include the Ganges, Irrawaddi, Salween, as well as rivers crossing borders of Thailand and Myanmar, or rivers draining into the Malacca strait in-between Malaysia and Indonesia.

Understanding the sources of nutrients in rivers is important for effective river basin management, and for understanding potential future loadings and effects. Human activities on land are the most important causes of increased nutrient inputs (especially $\mathrm{N}$ ) to rivers and of coastal eutrophication (Howarth 2008). Damming of rivers also affects river water quality. Nutrient retention in rivers may increase as a result of damming and consumptive water use. As a result, less nutrients are transported to coastal seas, potentially offsetting the increase in export due to human activities on land. This holds especially for particular forms of N and P (Suwarno et al. 2014b).

Since the industrial revolution, worldwide, the twentieth century meant exponential increases in both nutrient loads and eutrophication (Howarth 2008), and damming and nutrient retention (Syvitski et al. 2005). Rivers draining into the Bay of Bengal transport increasing amounts of nutrients from land to sea (Seitzinger et al. 2010). Past trends (1970-2000) in Sattar et al. (2014) and Suwarno et al. (2014b) suggest a net increase in nutrient export even with increased river damming. Sources of nutrients include fertilizers used in agriculture (De et al. 2011; Subramanian 2008), urbanization and domestic sewage (Pote et al. 2012), and aquaculture (Chua Thia et al. 1989; Das et al. 2004). Future changes in nutrient pollution are associated with population growth and urbanization (UNPD 2013; UNPD 2015), but also with changes in hydrology and damming (Seitzinger et al. 2010; Suwarno et al. 2014b).

Although hypoxia and algal blooms have been reported along the coastlines of the BOB LME, no systematic monitoring of coastal eutrophication exists. There are only a few experimental studies that report nutrient concentrations on an annual basis for rivers discharging into the BOB LME. Likewise, there are only a few analyses of major sources of nutrients in these rivers (Panigrahi et al. 2007; Sundaramanickam et al. 2008).

Recently, two modeling studies have been published on transboundary rivers in the Bay of Bengal. Sattar et al. (2014) analyzed the impact of food production (agriculture and aquaculture) on nutrient export by selected rivers to the Bay of Bengal. And Naeema and Kroeze (2014) presented perspectives of citizens on nutrient export by urban areas in Bangladesh, India, and Myanmar. These two studies indicate that, in the future, human activities may result in considerable increases in nutrient loadings of the rivers. However, these analyses are not complete, as they focus on selected rivers, or selected drivers of nutrients in the BOB LME. Their studies also lack spatial analyses of the sources of nutrients in rivers.

In this study, we, therefore, analyze current and future trends in river export of nutrients to the Bay of Bengal LME up to 2050 , and the associated potential for coastal eutrophication. Our analysis differs from earlier studies in that (1) we include the complete drainage basin; (2) we include all sources of nutrients in rivers, and a spatial analysis of these sources; and (3) we calculate nutrient export on the basis of observed hydrology where available rather than modeled hydrology.

River-delivered inputs of nitrogen $(\mathrm{N})$, phosphorus (P), and silica ( $\mathrm{Si}$ ) to the Bay of Bengal for the year 2000, and for a future scenario for the years 2030 and 2050, are calculated using the Global NEWS (Nutrient Export from WaterSheds) approach (Mayorga et al. 2010; Seitzinger et al. 2010). Major $\mathrm{N}$ and $\mathrm{P}$ sources are identified (including sewage, agriculture from crops and from livestock, atmospheric deposition directly to watershed). We also present the Indicator of Coastal Eutrophication (ICEP) (Garnier et al. 2010) for rivers draining watersheds of the BOB LME. The calculations for future years are based on one scenario from the Millennium Ecosystem Assessment (MEA) (Alcamo et al. 2005).

\section{Method}

\section{A modeling approach for the Bay of Bengal}

We adapted the Global NEWS 2 (hereinafter defined as "Global NEWS") approach for the Bay of Bengal (see Online Resource 1 for an overview of the modeled 133 river basins). Global NEWS is a global, spatially explicit model of nutrient export from land to sea. It models river export of dissolved and particulate forms of N, P, and Si to coastal waters. For details, we refer to Global NEWS publications (Mayorga et al. 2010; Seitzinger et al. 2010) and for an overview we refer to the supporting material (Online Resource 2).

We modified the Global NEWS 2 approach in two ways. First, we used observed rather than modeled hydrology for the BOB LME basins. Using observed hydrology results in a more realistic simulation of hydrological conditions (see Mayorga et al. 2010). Thus, we used climate observations (New et al. 1999) as drivers for the hydrological model (Water Balance Model Plus, WBMplus), and a dischargegauge correction (Fekete et al. 2002). As in the global application, we do this for the year 2000 (Mayorga et al. 2010; Seitzinger et al. 2010). Future hydrology was scaled to the 
observed hydrology in the year 2000 as described below (Eq. (6)).

Second, we aggregated small river basins into larger calculation units (Eq. (1)). We did this because Global NEWS output is known to be less accurate for basins consisting of only a few grid cells (Mayorga et al. 2010). By aggregating basins, we eliminate part of the uncertainty associated with the size of basins.

\section{Basin aggregation}

We first selected Global NEWS basins that drain into the BOB LME using the 2013 revision of the LME polygon boundaries shapefile obtained from http://www.lme.noaa.gov. An initial selection of Global NEWS basins to the BOB LME was performed via an automated procedure that expanded (buffered) the LME polygon boundary by $0.3^{\circ}$ (approximately $33 \mathrm{~km}$ at the equator, decreasing with latitude) and selected Global NEWS basin polygons that intersected this expanded boundary. This step was followed by manual assessment and correction. As a result, 133 exoreic Global NEWS basins were assigned to the BOB LME (see Online Resource 1). Many of these basins are small and contain relatively few input grid cells $\left(0.5 \times 0.5^{\circ}\right.$ for most inputs) per basin. Model output is less reliable for basins consisting of a few grid cells. Therefore, we aggregated basins following the principles of spatial adjacency. Basins that cover less than 10 grid cells and are adjacent to each other are aggregated, resulting in nine "combined basin regions." All results in this report are for these "combined basin regions" and for the 13 largest individual basins.

The Global NEWS model was then used to analyze the following model output by river basin: annual river export of $\mathrm{N}$ by form (DIN, DON, PN), total N (sum of $\mathrm{N}$ forms), $\mathrm{P}$ by form (DIP, DOP, PP), total P (sum of P forms), and dissolved Si. River export of nutrients is presented as load (Tg/ year) or yield $\left(\mathrm{kg} / \mathrm{km}^{2}\right.$ basin/year). Moreover, the relative share of sources of nutrients in rivers are identified (Online Resource 2), including diffuse and point sources. Diffuse sources include natural soils, fertilizer leaching from crop production and animal production, and atmospheric $\mathrm{N}$ deposition. Point sources are from urban wastewater (human sewage) exports. Modeled yields for "combined basin regions" have been aggregated by summing the loads of the individual basins and dividing by total basin area as in Eq. (1):

$x_{\text {yield }}=\frac{\sum_{i=1}^{n}\left(w_{\text {area basin }} \cdot x_{\text {yield }}\right)}{\sum_{i=1}^{n} w_{\text {area basin }}}$

In order to estimate the potential for eutrophication in the near-shore waters of the Bay of Bengal we calculate, for each river basin, the Indicator for Coastal Eutrophication Potential (ICEP), which is based on the Redfield molar ratio $(\mathrm{C} / \mathrm{N} / \mathrm{P} /$
$\mathrm{Si}=106: 16: 1: 20)$ (Garnier et al. 2010). This indicator assumes that $\mathrm{N}$ and $\mathrm{P}$ levels in excess of Si may favor growth of potentially harmful non-siliceous algae.

We calculate ICEP following Garnier et al. (2010); ICEP is calculated for $\mathrm{N}$ (when $\mathrm{N}$ is limiting) and $\mathrm{P}$ (when $\mathrm{P}$ is limiting) as follows:

$$
\begin{aligned}
& \mathrm{N}-\mathrm{ICEP}=[\mathrm{NFlx} / 14 \cdot 16-\mathrm{SiFlx} / 28 \cdot 20] \cdot 106 \cdot 12 \\
& \mathrm{P}-\mathrm{ICEP}=[\mathrm{PFlx} / 31-\mathrm{SiFlx} / 28 \cdot 20] 106 \cdot 12
\end{aligned}
$$

where:

PFlx, NFlx, and SiFlx are the fluxes (yields) of total N (TN), total P (TP), and dissolved silica (DSi), respectively, delivered at the mouth of the river. N, P, and silica fluxes are expressed in kilogram/square kilometer basin/day. ICEP is expressed in kilogram $\mathrm{C} /$ square kilometer/day. Total $\mathrm{N}$ and $\mathrm{P}$ fluxes are calculated as the sum of the three constituent elemental forms as shown in Eqs. (4) and (5), whereas silica fluxes are derived from Beusen et al. (2009):

$$
\begin{aligned}
& \text { NFlx }=\text { DINyield }+ \text { DONyield }+ \text { PNyield } \\
& \text { PFlx }=\text { DIPyield }+ \text { DOPyield }+ \text { PPyield }
\end{aligned}
$$

Considering that the $\mathrm{N} / \mathrm{P}$ ratio is indicative of which nutrient ( $\mathrm{N}$ or $\mathrm{P})$ is most limiting, we have opted for a combined ICEP (indicated simply as ICEP) for which we use the $\mathrm{N}$ or $\mathrm{P}$ ICEP with the lowest value (Garnier et al. 2010).

A negative ICEP $($ ICEP $<0)$ indicates a low potential for non-siliceous algae development. A positive ICEP (ICEP $>0$ ) indicates a potential risk of harmful algal blooms.

\section{Future scenario analysis}

We analyze a future scenario for the years 2030 and 2050, based on the Global Orchestration MEA scenario (Alcamo et al. 2005). Input databases to Global NEWS for future scenario analysis include several anthropogenic drivers derived directly from the MEA storylines. Additional inputs for nutrient management scenarios have been developed and added to these storylines to generate quantitative nutrient management scenarios and the input datasets for the Global NEWS model. In brief, the MEA scenarios consist of internally consistent, plausible global futures and their implications for ecosystem services which differ in terms of environmental management (proactive and reactive) and in their degree and scale of international integration (globalization or regionalization) growth (Alcamo et al. 2005).

As increased urbanization, and intensification of agriculture and economic activities (FAOSTAT 2015; UNPD 2013), are likely major drivers of increased nutrient loads in the Bay of Bengal, future trends for the years 2030 and 2050 are analyzed for the GO scenario. 
Input datasets for the 2030 and 2050 Global Orchestration (GO) scenario analysis were taken from earlier Global NEWS studies (Seitzinger et al. 2010) and are summarized in Online Resource 2.

Previous scenario analyses using Global NEWS were based on modeled climate drivers ("Modeled Hydrology") for both the year 2000 and future conditions (Seitzinger et al. 2010). Here, we modeled future conditions according to "Realistic Hydrology" for the year 2000. We scaled future nutrient export rates ("X") as follows:

$$
\begin{aligned}
X_{\text {year }}= & \left(X_{2000 \text { Realistic Hydrology }} / X_{2000 \text { Modeled Hydrology }}\right) \\
& \times X_{\text {year Modeled Hydrology }}
\end{aligned}
$$

where:

"year" is the scenario year (2030 or 2050) and ( $X_{2000}$ Realistic Hydrology $/ X_{2000}$ Modeled Hydrology $)$ is the scaling factor.

\section{River export of nutrients and eutrophication potential in the Bay of Bengal 2000-2050}

\section{Drivers of $N$ and $P$ export by rivers}

Important drivers of changes in $\mathrm{N}$ and $\mathrm{P}$ export by rivers include trends in population, GDP, and the associated $\mathrm{N}$ and $\mathrm{P}$ inputs to soils and changes in hydrology (See Online Resource 3 for the complete table of drivers).

According to the GO scenario, GDP increases faster than population between 2000 and 2050 in the BOB LME. The population density increases by about one third, and the urban population by about two thirds. GDP is projected to increase by a factor 7-11. However, there are regional differences. Basins in the Indian subcontinent have more or less similar trends with a GDP PPP (Purchasing Power Parity) between 1900 and 2200 1994US\$/inhabitants/year (Global NEWS input data, see Van Drecht et al. (2009) for calculations). The lowest GDP PPP is calculated for Myanmar, Irrawaddy, and Bangladesh basin regions with, respectively, 1107, 1242, and 1422 1994US\$/inhabitants/year, whereas the highest GDPs PPP in 2000 are in Malaysia, Thailand, Sri Lanka, and Indonesia (respectively, 8144, 3800, 3138, and 2915 1994US\$/inhabitants/year). Higher population densities are found in, for instance Damodar, parts of India, and Bangladesh with $>500$ inhabitants $/ \mathrm{km}^{2}$. Generally, basins in the eastern part of the Bay of Bengal have lower population and urban population densities, with the exception of Malaysia where in spite of a relatively low average population, the urban population density is 133 inhabitants $/ \mathrm{km}^{2}$, the third highest in the BOB LME. These trends are projected to continue in the future for both population and GDP growth. Basins with the highest GDPs PPP in 2050 are calculated to
Fig. 1 Selected drivers of nutrient export in the Bay of Bengal: $N$ and $P$ from fertilizer and manure application and population density highlighting spatial variability in the Bay of Bengal for the year 2000 (in $\mathrm{kg} / \mathrm{km}^{2} /$ year) and changes 2030-2000 and 2050-2000 (in $\mathrm{kg} / \mathrm{km}^{2}$ / year) for the Global Orchestration scenario

also have the highest GDPs PPP in the year 2000, with the exception of Sri Lanka.

Total inputs of $\mathrm{N}$ and $\mathrm{P}$ to rivers from point sources (sewage) are projected to increase by more than a factor of three between 2000 and 2050 in the GO scenario. This is mainly a result of the population increase and the assumed increase in the percentage of people connected to sewage systems (Van Drecht et al. 2009). In addition, the amount of P in sewage may increase because of a more widespread use of $\mathrm{P}$ detergents. Point sources are calculated to increase faster in time than diffuse sources. For the year 2000, we only calculate considerable sewage inputs for Damodar, South East India (India 2), Malaysia, Indonesia (Sumatra), and the Ganges. In the future, inputs from point sources will increase relatively fast, up to $27 \%$ of total nutrient inputs for Damodar. By 2050, there are sewage inputs to almost all river basins, since more people are assumed to be connected to sewage systems.

Inputs to land from fertilizer and manure are projected to increase by $60-155 \%$ between 2000 and 2050 . These increases are larger than the population increase. This could be explained by an increase in per capita caloric intake and meat consumption. Highest $\mathrm{N}$ and $\mathrm{P}$ input are found in the western part of the Bay of Bengal: in GHAAS basin 404, followed by South East India (India 2), Penner, Damodar, Cauweri, and Krishna (the latter mostly because of $\mathrm{P}$ from fertilizer). These basins are also among the most populated, with population densities above 500 inhabitants $/ \mathrm{km}^{2}$ in the year 2000 (Fig. 1). Spatial distributions of both population densities and $\mathrm{N}$ and $\mathrm{P}$ inputs from diffuse sources are projected to follow similar patterns to the reference year in the future (Fig. 1). $\mathrm{N}$ inputs from fertilizer and manure and $\mathrm{P}$ inputs from manure will increase up to $>16 \mathrm{~kg} / \mathrm{km}^{2} /$ year in large parts of the western part of the Bay of Bengal, but also in parts of southern Myanmar and Indonesia.

\section{River export of nutrients in the BOB LME (2000-2050)}

In 2000, rivers exported 7.1 Tg N to the BOB LME (Fig. 2), of which $4.1 \mathrm{Tg}$ as DIN, $0.9 \mathrm{Tg}$ as DON, and $2.1 \mathrm{Tg}$ as PN. In the GO scenario, the loads increased fastest between 2000 and 2030 , of which we calculated a $27 \%$ increase for DIN and $12 \%$ increase for DON. Meanwhile, PN loads decreased by $18 \%$ between 2000 and 2030 as a result of increased retention in dammed reservoirs. By 2050, total $\mathrm{N}$ load may amount to $8.6 \mathrm{Tg}$. This increase is mainly caused by a $45 \%$ increase in DIN loads from 4.1 Tg in 2000 to $6.0 \mathrm{Tg}$ in 2050. The two main sources of DIN in rivers are fertilizers and manure 


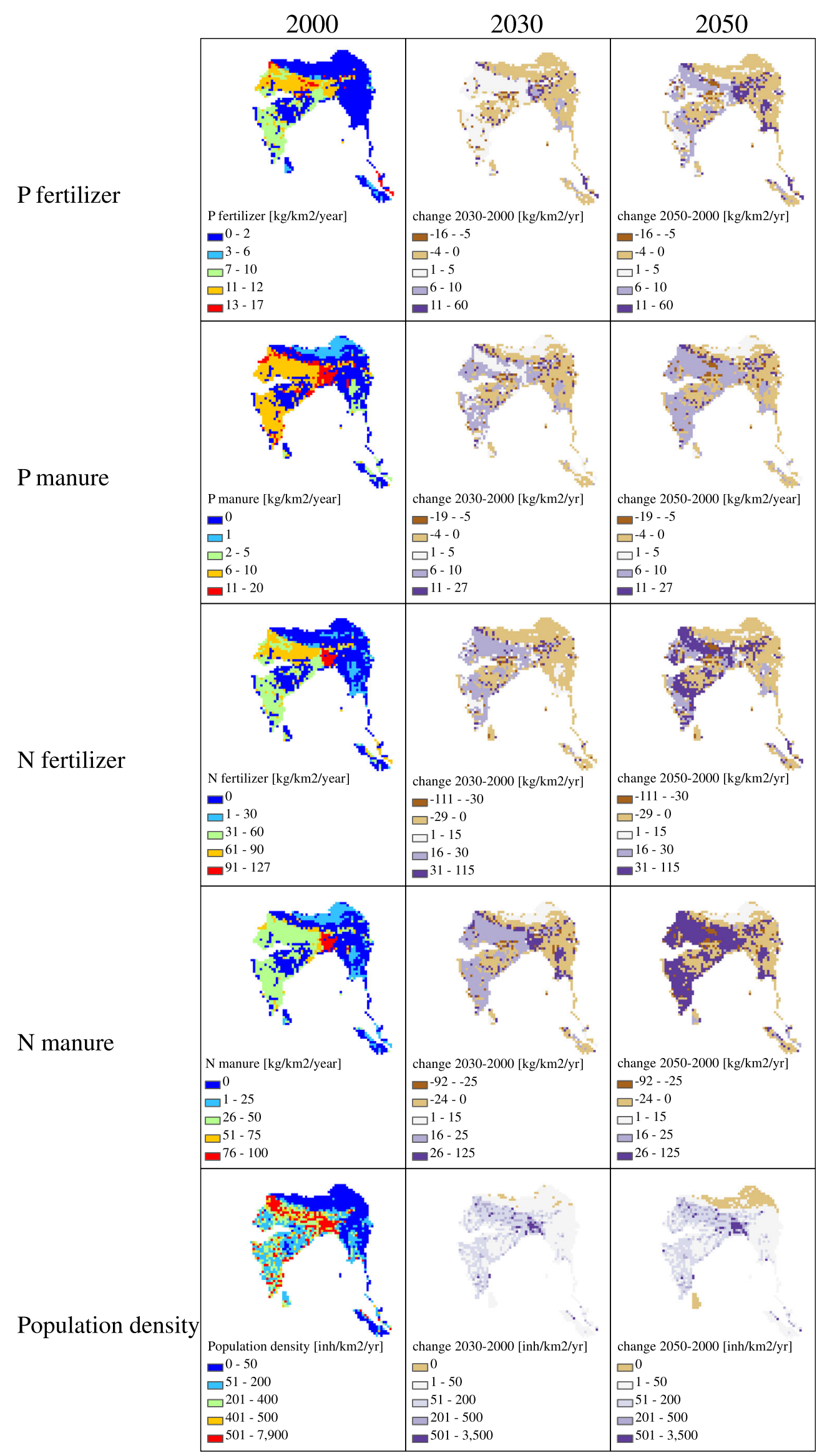


(Fig. 3), accounting for 32 and $26 \%$ of the total DIN loads for the year 2000, respectively.

Loads of DON (0.9 Tg in 2000) are small compared to DIN (4.1 Tg) and PN (2.1 Tg) (Fig. 3). In 2000, about $90 \%$ of the DON was from leaching with similar amounts from agricultural and natural areas (42 and 48\% respectively). In 2050, leaching accounts for $73 \%$ of the total DON load, and sewage for $18 \%$ according to the $\mathrm{GO}$ scenario.

Unlike dissolved $\mathrm{N}$ and $\mathrm{P}$ loads, particulate $\mathrm{N}$ and $\mathrm{P}$ loads are expected to decrease in the future. This can be explained by increased damming of rivers in the GO scenario, which results in increased particulate retention. This effect is most visible for PP which decreases by $27 \%$, i.e. from $1.2 \mathrm{Tg}$ in 2000 to $0.9 \mathrm{Tg}$ in 2050 (Fig. 2).

Total P exports amounted to $1.5 \mathrm{Tg} \mathrm{P}$ in 2000. TP loads do not change a lot over time (Fig. 2). This is a net effect of the decreasing trend in PP loads and increases in DIP (92\% increase, i.e., from $0.2 \mathrm{Tg}$ in 2000 to $0.5 \mathrm{Tg}$ in 2050) and DOP ( $21 \%$ increase, i.e., from $0.05 \mathrm{Tg}$ in 2000 to $0.06 \mathrm{Tg}$ in 2050 ).

In $2000,69 \%$ of DIP export can be attributed to agriculture (fertilizer and manure) (Fig. 3). In the future, sewage may become more important. By 2050, point sources (sewage) are calculated to account for $39 \%$ of the total DIP load, or $0.2 \mathrm{Tg} \mathrm{P} /$ year based on the GO scenario.

The DOP load was $0.05 \mathrm{Tg}$ in 2000 (Fig. 2). Leaching from natural and agricultural land was the dominant source of DOP in 2000 (accounting for $79 \%$ of the load) with fertilizer and manure accounting for the remaining $20 \%$ (10\% each). According to the GO scenario, by 2050 , fertilizer and manure account for 17 and $15 \%$ of the total DOP loads, respectively.

\section{Patterns in nutrient export and source attribution across BOB LME watersheds (2000-2050)}

\section{Nutrient loads and yields}

Two units for nutrient export are used in this study, load and yield. Load is expressed as the total amount of an element (e.g., N, P, Si by form) exported from the watersheds to the mouth of the river, in units of teragrams per year $\left(\mathrm{Tg}=10^{12} \mathrm{~g}\right)$.
Yield is also the amount of an element exported to the mouth of the river but is normalized by basin areas with units of kilogram per square kilometer of watershed per year. Yield can provide insight into the intensity of anthropogenic activity in a watershed. Yield is particularly useful in comparing the intensity of nutrient export across watersheds of widely different sizes. Because eutrophication in coastal systems is related more to the amount (load) rather than the yield of nutrients exported, we focus hereinafter on loads and provide future trends for yields in Online Resource 4. Ratio of nutrients (N, $\mathrm{P}$, and $\mathrm{Si}$ ) is important in determining the response of coastal systems to nutrient export. Algal blooms develop locally and temporally, and depend on nutrient loads, ratios, and local conditions. The river nutrient loads and ratios from BOB LME rivers likely most directly affect the near coastal regions (estuaries, bays), as they would be substantially altered through biological processing and dilution both within near coastal regions and in open waters of the BOB LME. Beyond nutrients, the particular morphological, climatic, and hydrological conditions, including temporal variations, also are important in determining the response of both near coastal systems and the open waters of the BOB LME to nutrient loads and ratios. Evaluating the exact response of the BOB LME to the river nutrient export would require further modeling and analysis with coastal hydrological-biogeochemical-ecosystem models.

The analysis of the total loads in the Bay of Bengal in the previous section gives insight in the magnitude of the total nutrient inputs to the BOB LME. Three rivers have a relatively large share in the total nutrient export: the Godavari, Ganges, and Irrawaddy. In the year 2000, these three basins were responsible for $79 \%$ of total DIN river export (load) to the BOB LME, $65 \%$ of total DON load, $76 \%$ of total DIP load, and $68 \%$ of total DOP load. The six rivers with the highest DIN loads are the Ganges, Irrawaddy, Godavari, Salween, Indonesia, and Mahanadi which are also six of the seven largest basins of the Bay of Bengal. As noted above, the degree of eutrophication (algal blooms, anoxia, etc.) in response to nutrient loads will be a function of not only the magnitude of the nutrient loading but also will depend on the local
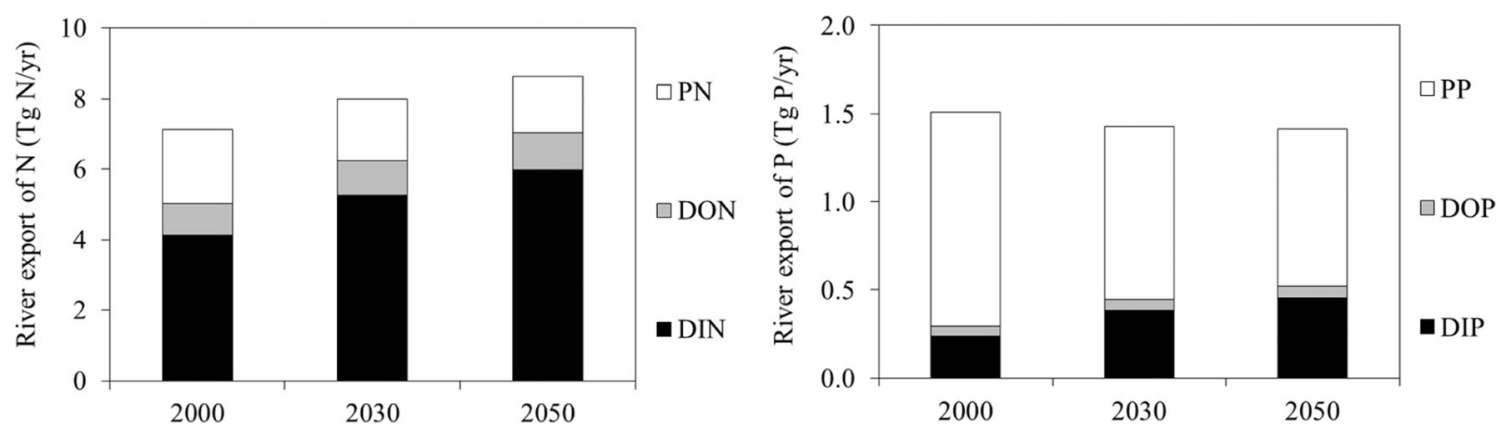

Fig. 2 River export of nitrogen and phosphorus to the Bay of Bengal for the years 2000, 2030, and 2050 (Global Orchestration Scenario). The graphs present dissolved inorganic N and P (DIN and DIP), organic N and P (DON and DOP), and particulate N and P (PN and PP) 
Fig. 3 Largest and second largest source of dissolved inorganic and organic nitrogen (DIN and DON) and dissolved inorganic and organic phosphorous (DIP and DOP) transported from watersheds to the mouth of the rivers in the Bay of Bengal in the year 2000, and according to the Global Orchestration scenario, in 2030 and 2050. The left side maps show the largest sources, and the right side maps show the second largest sources

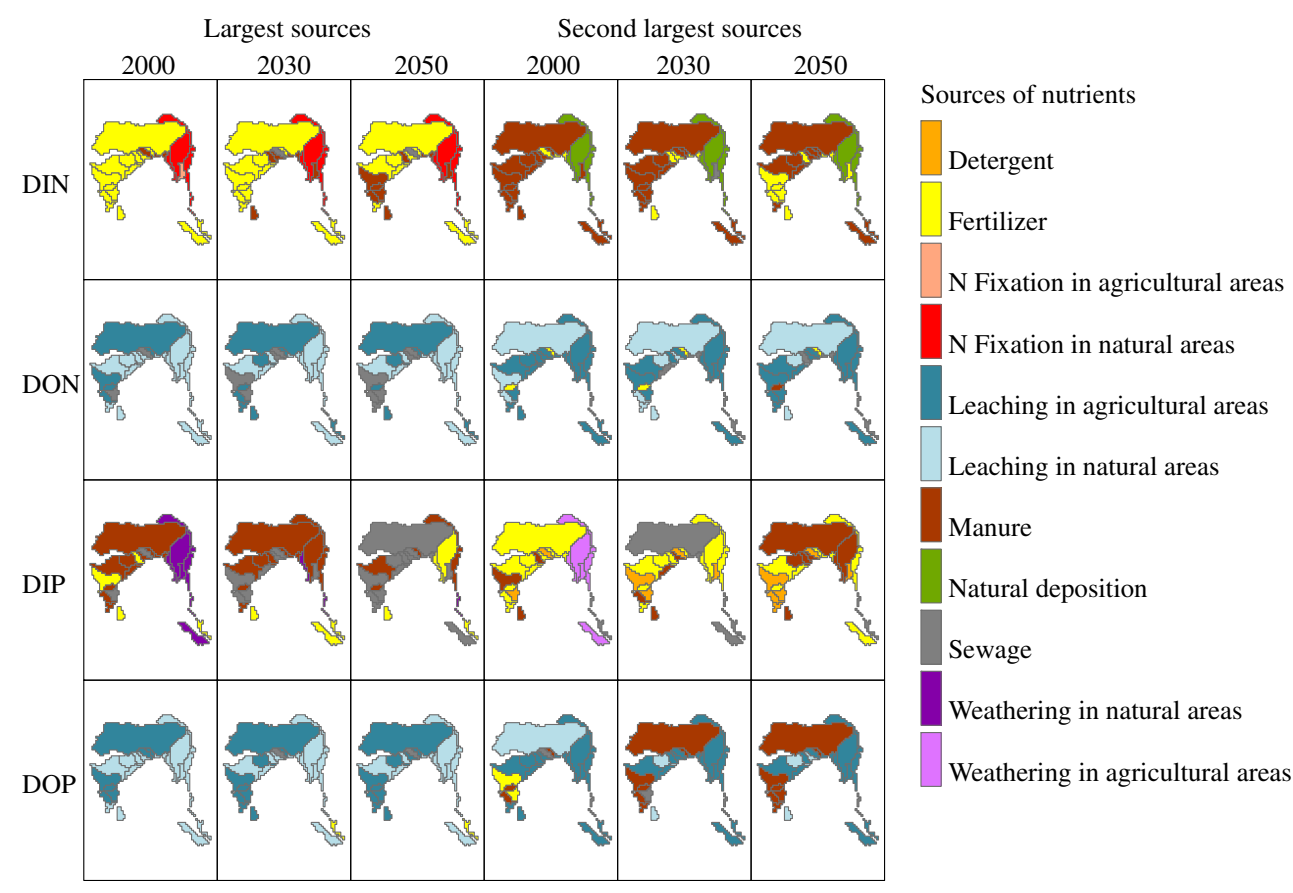

morphological and hydrological conditions. Therefore, rivers with smaller nutrient loads can also lead to eutrophication in estuaries and bays. Furthermore, rivers with large discharges might rapidly transport their nutrients and their effects further offshore.

\section{Nutrient sources}

Changes in nutrient export by rivers are the net effect of changes in $\mathrm{N}$ and $\mathrm{P}$ input to watersheds from human activities, and changes in hydrology as a result of damming, consumptive water use, and climate change. Here, we focus on anthropogenic sources of dissolved $\mathrm{N}$ and $\mathrm{P}$ in rivers (Fig. 3).

Fertilizers and manure are the two largest sources of DIN, 32 and $26 \%$ respectively, in rivers draining into the BOB LME. Only $22 \%$ comes from natural deposition and N fixation in natural areas; $19 \%$ from anthropogenic $\mathrm{N}_{2}$ fixation and atmospheric deposition in agricultural areas. Sewage makes up only $1 \%$ of total DIN load in 2000. Exceptions are in eastern rivers where $\mathrm{N}_{2}$ fixation in, and atmospheric $\mathrm{N}$ deposition to, natural soils are generally the dominant sources of DIN. By 2030 and 2050, contribution from each source will vary little $+/-3 \%$, and $+/-4 \%$, respectively, though total loads of DIN will increase by $27 \%$ (from $4.14 \mathrm{Tg} /$ year in 2000 to 5.27 and $5.99 \mathrm{Tg} /$ year in 2030 and 2050, respectively). That means that all sources of DIN will contribute proportionally similarly to 2000 trends. Fertilizers and manure will still provide the major contribution to DIN loads up to 2050 . However, the relative contribution will slightly decrease: in 2050, fertilizers and manure will contribute with 27 and $29 \%$, respectively, to the total load and sewage will constitute
$5 \%$ of total DIN loads. In the BOB LME overall, these trends can be explained by a relatively fast increase in manure input (more than a doubling by 2030 already) and pressure due to population growth and population connected to sewage. The relative share of sources of DIN in eastern BOB LME rivers will not change much. For most other rivers, agriculture (fertilizer and increasingly manure) remains the largest sources of DIN. An exception is the Damodar River where sewage inputs are projected to become dominant.

Leaching was the main source of DON ( $90 \%$ of the total) in all BOB LME rivers in the year 2000, with the exception of a few watersheds where sewage and fertilizer are the two largest sources of DON. The other sources in 2000 were sewage $(3 \%)$, manure (3\%), and fertilizer (4\%). Total loads of DON will increase by $19 \%$, from $0.88 \mathrm{Tg} /$ year in 2000 to $1.04 \mathrm{Tg} /$ year in 2050 (Fig. 2). Leaching from natural areas is generally larger than leaching from agricultural areas, with 0.42 and $0.37 \mathrm{Tg} /$ year in 2000 . Loads from leaching will decrease sensibly: in 0.42 and $0.35 \mathrm{Tg} /$ year in 2030 and 0.41 and $0.36 \mathrm{Tg} /$ year in 2050. However, the proportion of total leaching will decrease dramatically, already in 2030 because of decrease in natural areas, increased $\mathrm{N}$ deposition in agricultural land. By then, sewage will make up for $14 \%$ of the total DON load and will increase from $0.03 \mathrm{Tg}$ /year in 2000 to $0.19 \mathrm{Tg}$ /year in 2050. There are big differences though across river basins: sewage will increase to become the third source of DON in 2050 in the two major rivers such as Ganges and Godavari, after leaching, and the main source in many Indian basins and in Thailand and Malaysia. In eastern basins of the BOB, leaching from natural areas will remain the main sources also in the future. 
A total of $0.24 \mathrm{Tg} /$ year of DIP were exported to the BOB. Compared to DIN, there is more variation in dominant DIP sources across basins. As with DIN, agriculture (manure and fertilizer) is important as a source of DIP in much of the BOB LME under 2000 conditions; $69 \%$ of total DIP loads come from manure (35\%) and fertilizers, $16 \%$ from sewage (including $4 \%$ from detergents), and $15 \%$ from weathering (of which $7 \%$ from agricultural areas). In some basins, sewage is the largest source of DIP. In a number of eastern basins in the BOB LME, natural weathering or weathering from agricultural soils are the two largest sources.

Projected future changes in sources of DIP follow from the projected urbanization in the BOB LME basins. Contribution of weathering from both agricultural and natural areas will decrease because of a decrease in loads from those sources (10 and 17\% decrease in natural and agricultural areas respectively). Instead, loads of DIP originating from sewage, detergents, manure, and fertilizer will increase between 2000 and 2030. The total, DIP load in 2030 will be $0.38 \mathrm{Tg} /$ year (of which two thirds originating from the Ganges). Loads of sewage will increase by $270 \%$ up to $(0.11 \mathrm{Tg} /$ year $)$ and detergents by $250 \%$ ( $0.03 \mathrm{Tg}$ /year) between 2000 and 2030 . Because manure and fertilizer will increase by 28 and $38 \%$, respectively, between 2000 and 2030, sewage contribution to the total DIP load in 2030 will be larger than in 2000. The share of DIP loads will be: fertilizer (29\%), sewage (28\%), manure (27\%), detergent $(7 \%)$, weathering in natural areas $(5 \%)$, and weathering in agricultural areas $(4 \%)$. The trends between 2000 and 2030 will continue also between 2030 and 2050, but slower. Total DIP loads will be $0.46 \mathrm{Tg} /$ year, with sewage becoming the main source, 0.14 and $0.04 \mathrm{Tg}$ /year loads of DIP from sewage and detergents, respectively. Fertilizers $(0.13 \mathrm{Tg} /$ year $)$, manure $(0.12 \mathrm{Tg} /$ year $)$, and weathering (in total $0.03 \mathrm{Tg} /$ year) will also contribute to the total load of DIP in 2050. In other words, by 2050, sewage is projected to be the largest source of DIP in most rivers, with agricultural sources and $\mathrm{P}$ in detergents second largest in many rivers. As a result of agricultural development, diffuse agricultural sources (fertilizer and manure) will be important sources of DIP in the large eastern basins and in Godavari and Penner in the Indian subcontinent.

Total DOP loads amount at $0.05 \mathrm{Tg} /$ year in 2000 and increase by $21 \%$ in 2050 . Seventy-nine percent of DOP loads in 2000 come from leaching from agricultural and natural areas, $10 \%$ from manure and $10 \%$ from fertilizer. The ranking will not change for the BOB as a whole, but speed of increase will be faster for sewage (including also detergents). Though increasing fast $(+556 \%$ in 2050 compared to 2000$)$, total loads from sewage will make up only $4 \%$ of total DOP loads in 2050. Leaching will account for 68 and $64 \%$ of total loads of DOP in 2030 and 2050, respectively. Fertilizer loads will double in 2050, reaching $0.01 \mathrm{Tg} /$ year in 2050 (similar load for to manure). While leaching from natural or agricultural areas is projected to remain the largest source of DOP in most rivers by 2050, manure becomes the second largest source in the Ganges, and the cluster of basins in southern India.

In this scenario, increased economic activity and food production lead to $\mathrm{N}$ and $\mathrm{P}$ inputs to both point and diffuse sources, manure, fertilizers, anthropogenic $\mathrm{N}_{2}$ fixation, and $\mathrm{N}$ deposition being major diffuse sources until 2050 in the Bay of Bengal. Practices aimed at closure of the (local) nutrient cycle are not included. For example, direct input of human $\mathrm{N}$ and $\mathrm{P}$ collected from households is not accounted for (Bouwman et al. 2009).

Input from sewage is expected to increase the loads of both $\mathrm{N}$ and P. Relative contribution of manure and fertilizers is expected to decrease, because larger shares of the population will be connected to the sewage system. Our analysis indicates that future DON and DIP loads may increase due to the fastgrowing inputs from sewage. Because point sources may be underestimated by Global NEWS (Suwarno et al. 2014a), DIP and DON future trends may capture the effect of increasing urbanization but underestimate the increase in loads.

\section{Effects on coastal ecosystems}

Eutrophication from excess anthropogenic nutrient inputs to coastal waters is an increasing problem in many areas around the world. Both nutrient loads and nutrient ratios are important determinants of the algal biomass and species composition that develop and consequently the negative effects on coastal systems (e.g., very high algal biomass, decrease in dissolved oxygen, toxin production, changes in ecosystem structure and function). ICEP is an indicator for assessing the potential effect of changing nutrient ratios (ratio of $\mathrm{N}$ and $\mathrm{P}$ to $\mathrm{Si}$ in river export) on coastal ecosystems (Garnier et al. 2010).

For the year 2000, lowest yields of DSi are generally distributed across basins in India, whereas relatively higher yields are calculated for the Ganges and eastern BOB LME rivers $\left(>2000 \mathrm{~kg} / \mathrm{km}^{2}\right)$. Future trends in DSi yields are projected to increase in some basins and decrease in others under the GO 2050 scenario. Future changes in water runoff and biological removal in reservoirs are two important factors that control DSi yields (Beusen et al. 2009).

Figure 4 presents ICEP values for BOB LME basins. Positive values (ICEP $>0$ ) indicate a risk for non-siliceous algal biomass (e.g., dinoflagellates) many of which produce toxins and otherwise disrupt near-shore coastal ecosystems (Glibert et al. 2010). Negative values (ICEP $<0$ ) indicate that on average silica is in excess over $\mathrm{N}$ or $\mathrm{P}$ for algal growth and as such diatom growth is favored rather than the growth of potentially harmful algal species. However, negative ICEP values do not guarantee that there is no coastal eutrophication, since high biomass algal blooms (e.g., diatoms) may develop due to high nutrient loads. Neither nutrient loads nor ICEP take into account the particular morphological, climatic, and 


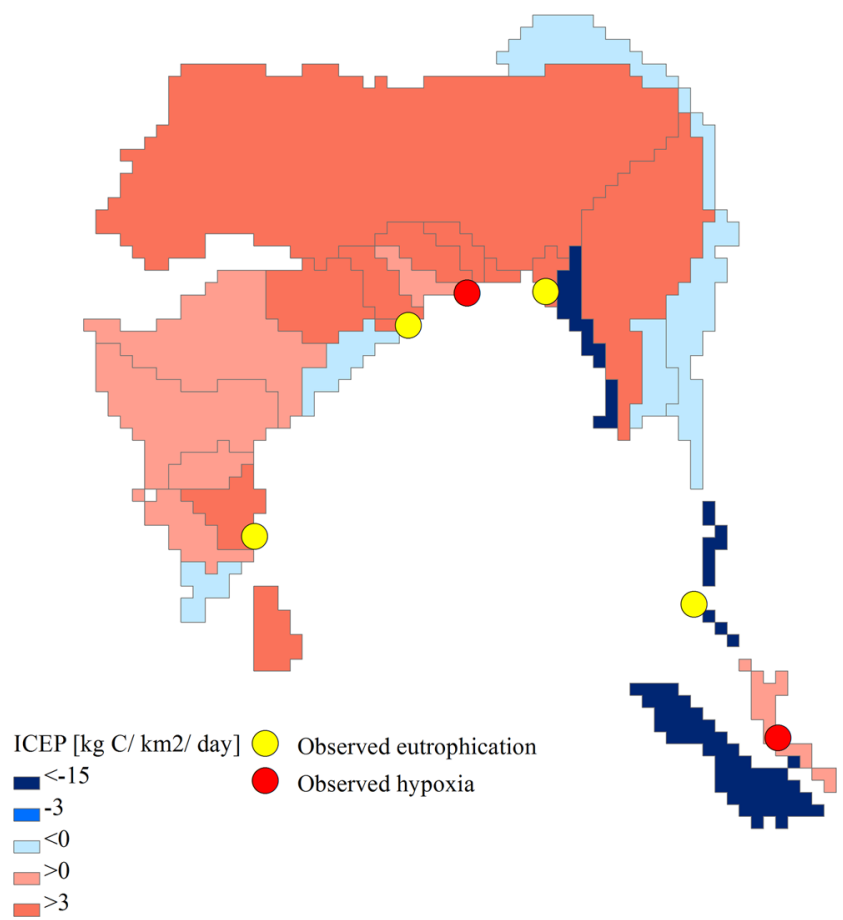

Fig. 4 Calculated ICEP for rivers draining into the Bay of Bengal for the years 2000. Yellow dots represent eutrophic sites, whereas red dots correspond to observed hypoxic conditions as reported by the World Resources Institute (Diaz et al. 2011). Both eutrophic and hypoxic conditions are generally observed during the 1990s and early 2000s, temporally in line with the Global NEWS2 reference year (2000)

hydrological conditions, including temporal variations, which also are important in determining the response of algae in coastal systems. However, as Garnier et al. (2010) have shown, positive ICEP values indicate that the yearly averaged $\mathrm{N}$ and $\mathrm{P}$ loads favor non-siliceous algal species, and should therefore be considered a strong indication that the coastal waters are at risk. As noted above for nutrient loads ("Nutrient loads and yields" section), the effects of river delivery of nutrients (loads and ratios) is likely most strongly expressed in near-shore receiving waters (estuaries and bays).

For the BOB LME basins, we generally calculate positive ICEP values indicating a risk for development of nonsiliceous algal biomass in the near coastal zone. By 2050, the ICEP values for a number of basins have become more positive than in 2000 , indicating an increased risk. There are a few exceptions. For Salween and Sittang, current low potential for non-siliceous algal biomass will remain low. ICEP in these basins was -1 and $-3 \mathrm{~kg} \mathrm{C} / \mathrm{km}^{2} /$ day in 2000 . The decrease in river export of particulate nutrients (especially for Salween) and an increase in DSi (especially for Sittang) compensate for an overall increase in dissolved $\mathrm{N}$ and $\mathrm{P}$ over time. We calculate a decreasing potential for coastal eutrophication for a number of smaller coastal river basins around the $\mathrm{BOB}$ LME. This is mostly associated with increasing DSi yields (e.g., Krishna and Indonesia with 264 and $9539 \mathrm{~kg} / \mathrm{km}^{2} /$ year in 2050 , or +26 and $+9 \%$ compared to 2000 yields).
In Fig. 4, we compare calculated ICEP values with observed hypoxic and eutrophic areas in the BOB LME. Although ICEP is an indicator for non-siliceous algal blooms, and therefore not directly comparable to hypoxia and eutrophication in terms of high nutrient concentrations, the comparison may be interesting. Most observed episodes (5 out of 6) of hypoxia and eutrophication are in areas for which a high ICEP was calculated. These eutrophied systems are the Uppanar Estuary located in South India, the northern section of the Chilika Lagoon which receives polluted water discharges from the Mahanadi river, the Ganges river basin, the Bakkhali estuary located in the Bangladesh aggregated basin, and the Port Klang system in the Malaysia aggregated basin. For these systems, there is a risk for algal bloom. We also note one observed episode of eutrophication with a low ICEP in Patong Island (Thailand aggregated river basin). This may either indicate a eutrophied system with a lower risk of algal bloom, or that a low ICEP does not guarantee that a system is safe.

\section{Comparisons with other studies and uncertainties}

Global NEWS was validated for rivers worldwide (Mayorga et al. 2010) and for all regional applications, including parts of the Bay of Bengal and Indonesia (Sattar et al. 2014; Suwarno et al. 2013). In all studies, the model performance has been evaluated as acceptable, with a similar performance for BOB LME in this study (Online Resource 2). For validation, we have analyzed three widely used indicators to assess model performance in predicting exports of dissolved $\mathrm{N}$ and $\mathrm{P}$ and suspended solids. Additionally, sensitivity analyses were also performed to assess the model parameters robustness for DIP and DIN modules globally (Dumont et al. 2005; Harrison et al. 2005). Although DIP and DIN sensitivity analyses were performed for the previous version of the Global NEWS model, the results are still valid for the current Global NEWS model version (Mayorga et al. 2010). The sensitivity analyses suggested that the model is relatively insensitive to uncertainty in most parameters, except for $\mathrm{N}$ retention for DIN and $\mathrm{P}$ retention in reservoirs for DIP. Output for DIP and DIN modules was more sensitive to changes in point sources for DIP and for diffuse sources in DIN. In the new version of NEWS models, point sources have been updated with estimates of detergent and improved calculations for human excretion ((point sources), see Van Drecht et al. (2009)) and newly calibrated retention parameter for DIN (diffuse sources) (Mayorga et al. 2010). See also Mayorga et al. (2010), Van Drecht et al. (2009), and Bouwman et al. (2009) for a detailed report in both inputs and parameterization improvements in Global NEWS models.

Further validation steps, such as statistical uncertainty and sensitivity analyses for all forms of nutrients are currently a challenge for the Bay of Bengal because of lack of further data 
for comparison. This problem has been already pointed out in similar South Asian-based studies (Sattar et al. 2014; Strokal et al. 2014). The validation datasets is largely based on the GEMS GLORI river discharge datasets (Meybeck and Ragu 1995). Further details on the validation datasets are published in Mayorga et al. (2010). To our knowledge, no other reliable measurements of dissolved $\mathrm{N}$ and $\mathrm{P}$ exist for the BOB LME.

As pointed out in Sattar et al. (2014), main uncertainties in such complex analyses relate to both model assumptions (parameters and model structure) and observations. We investigated model uncertainties by comparing our results to earlier studies for the Bay of Bengal (Naeema and Kroeze, 2014; Sattar et al. 2014; Suwarno et al. 2013) and for other world regions. We learn from this comparison that we may be missing sources of nutrients, including point sources from human and animal waste (e.g. Suwarno et al. 2014a; Suwarno et al. 2014b) and aquaculture (Liu et al. 2009), although this may be a relatively small source for the Bay of Bengal (Sattar et al. 2014), and atmospheric N deposition on sea (close to urban industrial areas). In order to partly address these shortcomings, we have chosen an internally consistent scenario analysis based on the Global Orchestration narrative. Although the future is unknown by definition, the Global Orchestration scenario has the advantage to describe strong economic development, fast urbanization, and overall increase in anthropogenic pressures. All these elements are consistent with current and past trends in the Bay of Bengal (O'Reilly and Louis 2014; Selvaraj et al. 2004).

South Asia has been defined a "hot spot" with $28 \%$ of the world TN and TP exoreic export (Mayorga et al. 2010). And the BOB LME alone represents about $17 \%$ of the world TN and TP export. However, the exact amount may vary, depending on sensitivity of parameters and improvements to the model. Suwarno et al. $(2014 \mathrm{a}, \mathrm{b})$ concluded that improving damming modeling by adding local data on dams and adding fish cultivation resulted in overall lower export of DIN and DIP for rivers in Indonesia. However, when including improved parameterization of sewage, all nutrient loads were higher. Similarly, such improvements may apply also for BOB LME export modeling, since common anthropogenic pressures across BOB LME countries still exist such as access to sanitation and open defecation (O'Reilly and Louis 2014), and aquaculture (Das et al. 2004; Islam 2003), etc.

Although these steps are promising, it is currently challenging to downscale Global NEWS for the BOB LME as a whole. Nutrient retention on land can be improved with processbased modeling (Suwarno et al. 2014b) and retention on sea by monitoring at the mouth of rivers and tributaries. However, both actions require systematic and extensive data collection and international cooperation. The current version of Global NEWS, therefore, should be interpreted more carefully for smaller basins, due to the scaling problem (Van der Struijk and Kroeze 2010). Small basins have not been addressed in past applications as individual basins, due to uncertainties related to their size and representation. However, they always were included in regional, continental, or global aggregations for completeness of mass balance and fluxes. As an improvement from early Global NEWS based analyses, we explicitly handle aggregations of small basins, in order to better address regional variability. However, in the optimal situation, a subbasin approach would help allocation of nutrient sources (Strokal et al. 2016) and therefore be more relevant for nutrient management policies, provided process-based modeling and monitoring to become possible.

\section{Conclusion}

In 2000, rivers exported 7.1 $\mathrm{Tg} \mathrm{N}$ and $1.5 \mathrm{Tg} \mathrm{P}$ to the Bay of Bengal. By 2050, the $\mathrm{N}$ load may amount to $8.6 \mathrm{Tg}$, while the $P$ load will not have changed much. This is the net effect of increasing loads for dissolved $\mathrm{N}$ and $\mathrm{P}$, and decreasing loads for particulate $\mathrm{N}$ and $\mathrm{P}$.

Future increases in dissolved $\mathrm{N}$ and $\mathrm{P}$ loads are associated primarily with increased $\mathrm{N}$ and $\mathrm{P}$ inputs to agriculture and with increasing population and economic developments. Future decreases in particulate $\mathrm{N}$ and $\mathrm{P}$ loads are associated with changes in hydrology, and with damming of rivers, increasing the retention of total suspended solids.

Agriculture is a dominant source of $\mathrm{N}$ and $\mathrm{P}$ in most rivers draining into the Bay of Bengal from India and Bangladesh in the western part of the drainage basin from northern Indian States and Bangladesh (mostly in the Ganges basin and delta) to southern Indian basins (Krishna, Cauweri, Penner) to Sumatra in Indonesia and Malaysia in the South East. The eastern part of the drainage basin (in particular Myanmar and Thailand) natural sources including leaching, fixation, and weathering are dominant although this may change in the future. In general, we may conclude that agriculture is and will remain an important source of dissolved inorganic $\mathrm{N}$ in rivers, while sewage will become the largest source of dissolved inorganic $\mathrm{P}$ in most basins.

Important drivers of river export of nutrients are population density and food production. These show large spatial variability. Population is high in Bangladesh, the northern states of India which are part of the Ganges drainage basin (>500 inhabitants $/ \mathrm{km}^{2}$ ). The same holds for $\mathrm{N}$ and $\mathrm{P}$ inputs to agricultural soils (fertilizer and manure). Other high input areas are found in southern India and Myanmar. These drivers will remain important also in the future.

$\mathrm{N}$ and $\mathrm{P}$ loadings in excess to Si loadings indicate a risk for potential non-siliceous harmful algal bloom. These coincide with observed coastal eutrophication and hypoxia. We generally calculate positive ICEP values for BOB LME rivers, indicating a risk for coastal eutrophication of non-siliceous algal blooms. In the future, based on the Global Orchestration 
scenario, the ICEP values are generally higher than in 2000 , indicating an increased risk.

The dominant sources of the different forms of $\mathrm{N}$ and $\mathrm{P}$ differ across basins. In addition to this, several rivers draining into the Bay of Bengal are transboundary rivers, with drainage areas in several countries. Examples include the Ganges and Salween, as well as rivers crossing borders of Thailand and Myanmar, or rivers draining into the Malacca strait inbetween Malaysia and Indonesia. Thus, effective management of coastal eutrophication calls for a basin-specific approach rather than national policies.

Next steps to consider for Bay of Bengal near coastal systems (estuaries, bays) would be to identify those near coastal systems with signs of eutrophication (e.g., high phytoplankton biomass, high abundances of harmful non-siliceous phytoplankton species such as dinoflagellates, low oxygen conditions, degradation of seagrass environments). The river basins draining into those coastal systems could then be targeted for nutrient reductions using the information on major nutrient sources provided in this paper. Projected future trends in nutrient loadings based on the scenario analysis presented here also could be used to avoid future eutrophication in specific coastal areas.

Acknowledgements This research was sponsored in the framework of the BOBLME project by the Global Environment Facility (GEF), Norway, the Swedish International Development Cooperation Agency (Sida), the Food and Agriculture Organization (FAO), and the National Oceanic and Atmospheric Administration (NOAA) of the USA.

Thanks to Wilbert van Vliet for his advice on cartography and ArcGIS, to Maryna Strokal for her advice on the final version of the abstract of this manuscript, and Mengru Wang for final layout checks.

Open Access This article is distributed under the terms of the Creative Commons Attribution 4.0 International License (http:// creativecommons.org/licenses/by/4.0/), which permits unrestricted use, distribution, and reproduction in any medium, provided you give appropriate credit to the original author(s) and the source, provide a link to the Creative Commons license, and indicate if changes were made.

\section{References}

Alcamo J, Van Vuuren D, Cramer W, Alder J, Bennett E, Carpenter S, Christensen V, Foley J, Maerker M, Masui T, Morita T, O’Neill B, Peterson B, Ringler C, Rosegrant M, Schulze R, Bouwman L, Eickhout B, Floerke M, Lal RKT, Sinh BT, Hammond A, Field C (2005) Chapter 9. Changes in ecosystem services and their drivers across the scenarios. In: Carpenter S, Pingali P, Bennet E, Zurek M (eds) Millennium ecosystem assessment, vol Volume 2. Scenarios. Island Press, Washington, pp 297-373

Beusen AHW, Bouwman AF, Dürr HH, Dekkers ALM, Hartmann J (2009) Global patterns of dissolved silica export to the coastal zone: results from a spatially explicit global model. Glob Biogeochem Cycles 23:GB0A02. doi:10.1029/2008GB003281

Bouwman AF, Beusen AHW, Billen G (2009) Human alteration of the global nitrogen and phosphorus soil balances for the period 1970-
2050. Glob Biogeochem Cycles 23:GB0A04. doi:10.1029/ 2009GB003576

Bricker SB, Longstaff B, Dennison W, Jones A, Boicourt K, Wicks C, Woerner J (2008) Effects of nutrient enrichment in the nation's estuaries: a decade of change. Harmful Algae 8:21-32. doi:10.1016/j. hal.2008.08.028

Buapet P, Hiranpan R, Ritchie RJ, Prathep A (2008) Effect of nutrient inputs on growth, chlorophyll, and tissue nutrient concentration of Ulva reticulata from a tropical habitat. Sci Asia 34:245-252. doi:10. 2306/scienceasia1513-1874.2008.34.245

Chua Thia E, Paw JN, Guarin FY (1989) The environmental impact of aquaculture and the effects of pollution on coastal aquaculture development in Southeast Asia. Mar Pollut Bull 20:335-343. doi:10. 1016/0025-326X(89)90157-4

Das B, Khan YSA, Das P (2004) Environmental impact of aquaculturesedimentation and nutrient loadings from shrimp culture of the southeast coastal region of the Bay of Bengal. J Environ Sci 16: 466-470

De TK, De M, Das S, Chowdhury C, Ray R, Jana TK (2011) Phytoplankton abundance in relation to cultural eutrophication at the land-ocean boundary of Sunderbans, NE Coast of Bay of Bengal, India. J Environ Stud Sci 1:169-180. doi:10.1007/s13412011-0022-3

Diaz R, Selman M, Chique C (2011) Global eutrophic and hypoxic coastal systems. Eutrophication and hypoxia: nutrient pollution in coastal waters. World Resources Institute docs.wri.org/wri_eutrophic hypoxic_dataset_2011-03.xls. Accessed 13 January 2017

Dumont E, Harrison J, Kroeze C, Bakker E, Seitzinger S (2005) Global distribution and sources of dissolved inorganic nitrogen export to the coastal zone: results from a spatially explicit, global model. Glob Biogeochem Cycles 19. doi:10.1029/2005GB002488

FAOSTAT (2015) Compare data: agri-environmental indicators - fertilizers http://faostat3.fao.org/compare. http://faostat3.fao.org/ compare/E. Accessed 31 May 2015

Fekete B, Vörösmarty C, Grabs W (2002) High-resolution fields of global runoff combining observed river discharge and simulated water balances. Global Biogeochemical Cycles 16 Glob Biogeochem Cycles 16:15-11-15-10. doi:10.1029/1999GB001254

Garnier J, Beusen AHW, Thieu V, Billen G, Bouwman AF (2010) N:P:Si nutrient export ratios and ecological consequences in coastal seas evaluated by the ICEP approach. Glob Biogeochem Cycles 24: GB0A05. doi:10.1029/2009GB003583

Glibert PM, Allen JI, Bouwman AF, Brown CW, Flynn KJ, Lewitus AJ, Madden CJ (2010) Modeling of HABs and eutrophication: status, advances, challenges. J Mar Syst 83:262-275. doi:10.1016/j. jmarsys.2010.05.004

Glibert PM, Allen JI, Artioli Y, Beusen AH, Bouwman L, Harle J, Holmes R, Holt J (2014) Vulnerability of coastal ecosystems to changes in harmful algal bloom distribution in response to climate change: projections based on model analysis. Glob Change Biol 20: 3845-3858. doi:10.1111/gcb.12662

Harrison JA, Seitzinger SP, Bouwman A, Caraco NF, Beusen AH, Vörösmarty CJ (2005) Dissolved inorganic phosphorus export to the coastal zone: results from a spatially explicit, global model. Glob Biogeochem Cycles 19:GB4S03. doi:10.1029/ 2004GB002357

Howarth RW (2008) Coastal nitrogen pollution: a review of sources and trends globally and regionally. Harmful Algae 8:14-20. doi:10. 1016/j.hal.2008.08.015

Islam MS (2003) Perspectives of the coastal and marine fisheries of the Bay of Bengal, Bangladesh. Ocean Coast Manag 46:763-796. doi: 10.1016/S0964-5691(03)00064-4

Islam MS, Jahangir Sarker M, Yamamoto T, Abdul Wahab M, Tanaka M (2004) Water and sediment quality, partial mass budget and effluent $\mathrm{N}$ loading in coastal brackishwater shrimp farms in Bangladesh. Mar Pollut Bull 48:471-485. doi:10.1016/j.marpolbul.2003.08.025 
Lee C-W, Bong C-W (2006) Carbon flux through bacteria in a eutrophic tropical environment: Port Klang waters. In: Wolanski E (ed) The environment in Asia Pacific Harbours. Springer, pp 329-345. doi: 10.1007/1-4020-3655-8_20

Liu D, Keesing JK, Xing Q, Shi P (2009) World's largest macroalgal bloom caused by expansion of seaweed aquaculture in China. Mar Pollut Bull 58:888-895. doi:10.1016/j.marpolbul.2009.01.013

Mayorga E, Seitzinger SP, Harrison JA, Dumont E, Beusen AH, Bouwman A, Fekete BM, Kroeze C, Van Drecht G (2010) Global nutrient export from WaterSheds 2 (NEWS 2): model development and implementation. Environ Model Softw 25:837-853. doi:10. 1016/j.envsoft.2010.01.007

Meybeck M, Helmer R (1989) The quality of rivers: from pristine stage to global pollution. Glob Planet Chang 1:283-309. doi:10.1016/09218181(89)90007-6

Meybeck M, Ragu A (1995) River discharges to the oceans: an assessment of suspended solids, major ions and nutrients. In: Environment Information and Assessment. U.N. Environment Programme. UNEP, Nairobi, p 1-245

Naeema ZJ, Kroeze C (2014) Future trends in urbanization and coastal water pollution in the Bay of Bengal: the lived experience. Environ Dev Sustain 17:531-546. doi:10.1007/s10668-014-9558-1

New M, Hulme M, Jones P (1999) Representing twentieth-century time climate variability. Part I: development of a mean monthly terrestrial climatology. J Clim 12:829-856. doi:10.1175/1520-0442(1999) 012<0829:RTCSTC $>2.0 . C O ; 2$

O'Reilly K, Louis E (2014) The toilet tripod: understanding successful sanitation in rural India. Health \& Place 29. doi:10.1016/j. healthplace.2014.05.007

Panigrahi S, Acharya B, Panigrahy R, Nayak B, Banarjee K, Sarkar S (2007) Anthropogenic impact on water quality of Chilika lagoon RAMSAR site: a statistical approach. Wetl Ecol Manag 15:113126. doi:10.1007/s11273-006-9017-3

Periyanayagi R, Sasikala V, Venkatesan R, Karthikayen R, Balasubramanian T (2007) Phytoplankton in relation to pollution in uppanar estuary southeast coast of India. Res J Environ Toxicol 1:153-157. doi:10.3923/rjet.2007.153.157

Pote SE, Singal S, Srivastava D (2012) Assessment of surface water quality of Godavari River at Aurangabad. Asian J Water, Environ Pollut 9:117-122

Sattar MA, Kroeze C, Strokal M (2014) The increasing impact of food production on nutrient export by rivers to the Bay of Bengal 19702050. Mar Pollut Bull 8:168-178. doi:10.1016/j.marpolbul.2014. 01.017

Seitzinger S, Mayorga E, Bouwman A, Kroeze C, Beusen A, Billen G, Van Drecht G, Dumont E, Fekete B, Garnier J (2010) Global river nutrient export: a scenario analysis of past and future trends. Glob Biogeochem Cycles 24:GB0A08. doi:10.1029/2009GB003587

Selvaraj K, Mohan VR, Szefer P (2004) Evaluation of metal contamination in coastal sediments of the Bay of Bengal, India: geochemical and statistical approaches. Mar Pollut Bull 49:174-185. doi:10. 1016/j.marpolbul.2004.02.006

Strokal M, Yang H, Zhang Y, Kroeze C, Li L, Luan S, Wang H, Yang S, Zhang Y (2014) Increasing eutrophication in the coastal seas of China from 1970 to 2050. Mar Pollut Bull 85:123-140. doi:10. 1016/j.marpolbul.2014.06.011

Strokal M, Kroeze C, Wang M, Bai Z, Ma L (2016) The MARINA model (Model to Assess River Inputs of Nutrients to seAs): model description and results for China. Sci Total Environ 562:869-888. doi:10. 1016/j.scitotenv.2016.04.071

Subramanian V (2008) Nitrogen transport by rivers of south Asia. Curr Sci 94:1413-1418

Sundaramanickam A, Sivakumar T, Kumaran R, Ammaiappan V, Velappan R (2008) A comparative study of physico-chemical investigation along Parangipettai and Cuddalore coast. J Environ Sci Technol 1:1-10. doi:10.3923/jest.2008.1.10

Suwarno D, Löhr A, Kroeze C, Widianarko B (2013) Past and future trends in nutrient export by 19 rivers to the coastal waters of Indonesia. J Integr Environ Sci 10:55-71. doi:10.1080/1943815x. 2013.772902

Suwarno D, Löhr A, Kroeze C, Widianarko B (2014a) Fast increases in urban sewage inputs to rivers of Indonesia. Environ Dev Sustain 16: 1077-1096. doi:10.1007/s10668-014-9514-0

Suwarno D, Löhr A, Kroeze C, Widianarko B, Strokal M (2014b) The effects of dams in rivers on $\mathrm{N}$ and $\mathrm{P}$ export to the coastal waters in Indonesia in the future. Sustainability Water Qual Ecol 3. doi:10. 1016/j.swaqe.2014.11.005

Syvitski JPM, Vörösmarty CJ, Kettner AJ, Green P (2005) Impact of humans on the flux of terrestrial sediment to the global coastal ocean. Science 308:376-380. doi:10.1126/science.1109454

Tripathy SC, Ray AK, Patra S, Sarma VV (2005) Water quality assessment of Gautami-Godavari mangrove estuarine ecosystem of Andhra Pradesh, India during September 2001. J Earth Syst Sci 114:185-190. doi:10.1007/bf02702020

UNPD (2013) United Nations, Department of Economic and Social Affairs, Population Division. World population prospects: the 2012 revision, highlights and advance tables. Working Paper No. ESA/P/WP.228. http://esa.un.org/unpd/wpp/index.htm. Accessed 31 May 2015

UNPD (2015) United Nations, Department of Economic and Social Affairs, Population Division. World urbanization prospects: the 2014 revision. Report No: ST/ESA/SER.A/366. http://esa.un.org/ unpd/wup/Country-Profiles/. Accessed 31 May 2015

Van der Struijk F, Kroeze C (2010) Future trends in nutrient export to the coastal waters of South America: implications for occurrence of eutrophication. Glob Biogeochem Cycles 24. doi:10.1029/ 2009GB003572

Van Drecht G, Bouwman AF, Harrison J, Knoop JM (2009) Global nitrogen and phosphate in urban wastewater for the period 1970 to 2050. Glob Biogeochem Cycles 23. doi:10.1029/2009gb003458 